\title{
PROBLEM OF POPULATION HEALTH PROTECTION AGAINST THE PROBABLE ACTION OF ENVIRONMENTAL FACTORS, CREATED IN THE PROCESS OF USE OF AIRPORTS OF CIVIL AVIATION UKRAINE
}

Yu.D. Dumansky, N.G. Nikitina, V.Yu. Dumansky, S.V. Bitkin, P.V. Semashko, L.A. Tomashevskaya, S.V. Zotov, A.P. Bezverha, E.A. Serdyuk, S.S. Galak, N.M. Stebliy,

The article discusses the situations that have developed in the territories of populated areas located in close proximity to modern airports. It raises the question of the need for a hygienic assessment of the combined effect of these factors, taking into account the definition of their real and permissible load on the population.

\section{ВПЛИВ СУМІСНОЇ ДІЇ ЕЛЕКТРОМАГНІТНОГО ПОЛЯ, ШУМУ ТА ТЕМПЕРАТУРА НА ПОКАЗНИКИ ЕНЕРГЕТИЧНОГО ОБМІНУ В ОРГАНІЗМІ ТВАРИН}

\author{
Томашевська Л.А., Кравчун Т.С., Нікітіна Н.Г. \\ ДУ «Інститут громадського здоров'я ім. О.М. Марзєєва НАМН Украӥни», м. Київ
}

Вступ. Останнім часом все більш наукових досліджень зосереджено на визначенні впливу сукупності факторів довкілля на здоров'я населення. Оцінка сумісної дії екологічних факторів хімічної, фізичної, біологічної природи є однією із складних гігієнічних проблем. В реальних умовах антропогенні зміни факторів довкілля впливають на населення одночасно сукупною дією.

Окрім комбінованої дії хімічних чинників вплив на здоров'я населення спричиняють також навантаження фізичними факторами. Сукупною дією фізичних факторів може бути посилення електромагнітного випромінювання, підвищення шуму, температурні коливання та інше. Визначення особливостей відповіді організму на екологічні зміни $\epsilon$ актуальним питанням. Попередніми роботами в нашому інституті вже досліджувалась сумісна дія двох фізичних факторів неіонізуючого та іонізуючого випромінювань. Було встановлено, що на фоні недіючого рівня іонізуючої радіації (цезій-137 на рівні НРБ-76/87) підсилювалась дія ЕМП за впливом на функціональний стан організму піддослідних тварин $[1,2]$.

Метою даної роботи була спроба визначення стану метаболічних процесів під впливом електромагнітного випромінювання, шуму та температури при одночасній сумісній дії в субхронічному експерименті.
Модель дії фізичних факторів складалась з блоків-схем: - блока випромінювальної системи, блока стабілізації шуму та блоку регулювання температури. Технічні параметри факторів (ЕМП 3000 МГц інтенсивністю - 100, 500, 2500 мкВт/см ${ }^{2}$, шум 85 дБА, температура $15^{0} \mathrm{C}$ ) щоденно контролювались. Контрольні тварини утримувались в умовах віварію при кімнатній температурі.

Експеримент проведено на білих безпородних щурах, які піддавались сумісній дії факторів впродовж 2-х місяців. Відбір біологічного матеріалу здійснювався через 1 та 2 місяці експерименту. В крові визначали активність ферментів ЛДГ та церулоплазміну в мітохондріях печінки та головного мозку рівень активності цитохромоксидази та сукцинатдегідрогенази та вміст глікогену в гомогенатах $[3,4]$.

Статистичну обробку виконували методом варіаційного аналізу з визначенням tкритерію Ст'юдента [5].

Експериментальні дослідження проведені у відповідності з національними вимогами біоетики у «Загальних етичних принципах експериментів на тваринах» та рекомендаціями Європейської конвенції [6].

При впливі на організм виникають порушення стабільності гомеостазу, що визначається біохімічними та фізілогічними змінами функціональних систем. Біохімічні 
дослідження дозволяють вивчити особливості стану окисно-відновлювальних метаболічних процесів в організмі піддослідних тварин, на підставі чого визначити основні закономірності характеру залежності реакції відповіді організму на вплив комплексу факторів. Вивчення цих ферментів дає уявлення про стан енергетичного обміну, оскільки вони каталізують реакції окислення пов'язані 3 фосфорилюванням.

В нормі рівень вуглеводів $є$ відносно постійною величиною, що говорить про збалансованість процесів надходження глюкози до крові та перетворення у глікоген. Співвідношення між концентрацією метаболітів у тканині та активністю ферментів характеризується високою специфічністю для визначення фізіологічних та патологічних станів.

Результати досліджень. Отримані результати досліджень біохімічних процесів під впливом комплексу факторів представлені у таблицях 1-3. У різні строки дослідження спостерігалось пригнічення активності ферментів, міцно структурованих з мембранами мітохондрій - сукцинатдегідрогенази та цитохромоксидази.

При поєднанні факторів: ЕМП 100, 500 та 2500 мкВт/см ${ }^{2}$, температура $15^{0} \mathrm{C}$ та шуму на рівні 85 дБА, через 30 діб від початку впливу спостерігається пригнічення мітохондріальних ферментів не залежно від органної належності та величини діючого рівня ЕМП. Активність цитохромоксидази в мітохондріях печінки достовірно знижена при дії ЕМП 500 та 2500 мкВт/см² відповідно на 10 та $12 \%$. Зміни цитохромоксидази в мітохондріях головного мозку можна було спостерігати під впливом всіх рівнів ЕМП при $\mathrm{p}<0,05$ (табл. 1).

Таблиця 1. Стан біохімічних показників щурів при сумісній дії ЕМП, шуму 85 дБА та температури $15^{\circ} \mathrm{C}$.

\begin{tabular}{|c|c|c|c|}
\hline \multirow{2}{*}{ Показники } & \multirow{2}{*}{ ЕМП, мкВТ/см ${ }^{2}$} & \multicolumn{2}{|c|}{ Період дії (місяці) } \\
\hline & & 1 місяць & 2 місяці \\
\hline \multirow{4}{*}{$\begin{array}{l}\text { Цитохромоксидаза в мітохондріях пе- } \\
\text { чінки, U/мг білку }\end{array}$} & 100 & $1,68 \pm 0,07$ & $1,61 \pm 0,06^{*}$ \\
\hline & 500 & $1,63 \pm 0,05^{*}$ & $1,60 \pm 0,05^{*}$ \\
\hline & 2500 & $1,61 \pm 0,06^{*}$ & $1,56 \pm 0,07^{*}$ \\
\hline & Контроль & $1,83 \pm 0,06$ & $1,86 \pm 0,06$ \\
\hline \multirow{4}{*}{$\begin{array}{l}\text { Цитохромоксидаза в мітохондріях го- } \\
\text { ловного мозку, U/мг білку }\end{array}$} & 100 & $1,41 \pm 0,03 *$ & $1,38 \pm 0,04^{*}$ \\
\hline & 500 & $1,36 \pm 0,06^{*}$ & $1,34 \pm 0,05^{*}$ \\
\hline & 2500 & $1,32 \pm 0,05^{*}$ & $1,51 \pm 0,04^{*}$ \\
\hline & Контроль & $1,54 \pm 0,04$ & $1,61 \pm 0,04$ \\
\hline \multirow{4}{*}{$\begin{array}{l}\text { Сукцинатдегідрогеназа в мітохондріях } \\
\text { печінки, U/мг білку }\end{array}$} & 100 & $1,64 \pm 0,04$ & $1,52 \pm 0,04^{*}$ \\
\hline & 500 & $1,62 \pm 0,06$ & $1,60 \pm 0,03 *$ \\
\hline & 2500 & $1,51 \pm 0,05^{*}$ & $1,47 \pm 0,05^{*}$ \\
\hline & Контроль & $1,72 \pm 0,04$ & $1,75 \pm 0,04$ \\
\hline \multirow{4}{*}{$\begin{array}{l}\text { Сукцинатдегідрогеназа в мітохондріях } \\
\text { головного мозку, U/мг білку }\end{array}$} & 100 & $1,35 \pm 0,05$ & $1,30 \pm 0,04$ \\
\hline & 500 & $1,30 \pm 0,03$ & $1,28 \pm 0,03^{*}$ \\
\hline & 2500 & $1,27 \pm 0,04 *$ & $1,25 \pm 0,03 *$ \\
\hline & Контроль & $1,41 \pm 0,04$ & $1,41 \pm 0,04$ \\
\hline
\end{tabular}

Примітка: * $-\mathrm{p}<0,05$.

Протягом першого місяця впливу суттєве пригнічення сукцинатдегідрогенази відмічено лише при ЕМП 2500 мкВт/см². Виявлені зміни активності мітохондріальних дегідрогеназ відзначені у більш пізні строки спостереження. Активність сукцинатдегідрогенази в мітохондріях печінки знижені у всіх дослідних групах тварин. Зберігається пригнічення цього ферменту і в мітохондріях головного мозку тварин.

Достовірно значуще знижується сукцинатдегідрогеназа мітохондрій печінки при дії ЕМП 100, 500 та 2500 мкВт/см². В мітохондріях головного мозку зниження актив- 
ності ферменту спостерігається в групах 3 навантаженням ЕМП на рівні 500 та 2500 мкВт/ $\mathrm{cm}^{2}$.

Пригнічення сукцинатдегідрогенази та цитохромоксидази свідчить про зниження окислювальної здатності мітохондрій під впливом вивчає мого комплексу факторів. В основі такого впливу, вочевидь, може лежатиме мбранопошкоджуючий ефект, оскільки сукцинатдегідрогеназа міцно пов'язана 3 внутрішньою мембраною мітохондрій, а цитохромоксидази перетинає мембрану від зовнішньої сторони до внутрішньої. Інгібуван- ня цих ферментів гальмує окислювальне формування на ФАД-залежних субстратах та дихальному ланцюгу.

Зміни активності мітохондріальних ферментів супроводжується змінами активності гліколізу, не пов'язаного субклітинними структурами - глікоген в гомогенатах тканин, ЛДГ у сироватці крові. Визначення вмісту глікогену в тканинах тварин показало, що зміни його рівня в печінці спостерігається як у ранні, так і у пізні строки дії факторів та складає 15-18\% в порівнянні з контрольною групою тварин (табл. 2).

Таблиця 2. Рівень глікогену в тканинах печінки та головного мозку щурів при сумісній дії ЕМП, шуму 85 дБА та температури $15^{\circ} \mathrm{C}$.

\begin{tabular}{|c|c|c|c|}
\hline \multirow{2}{*}{ Показники } & \multirow{2}{*}{ ЕМП, мкВт/см ${ }^{2}$} & \multicolumn{2}{|c|}{ Період дії (місяці) } \\
\hline & & 1 місяць & 2 місяці \\
\hline \multirow{4}{*}{ Глікоген в печінці, ммоль/г } & 100 & $71,0 \pm 2,60$ & $71,0 \pm 2,70 *$ \\
\hline & 500 & $70,2 \pm 3,14^{*}$ & $70,0 \pm 2,38^{*}$ \\
\hline & 2500 & $69,4 \pm 3,35^{*}$ & $68,8 \pm 2,27 *$ \\
\hline & Контроль & $84,0 \pm 3,03$ & $84,2 \pm 2,60$ \\
\hline \multirow{4}{*}{ Глікоген в мозку, ммоль/Г } & 100 & $17,4 \pm 0,65$ & $18,0 \pm 0,66$ \\
\hline & 500 & $19,1 \pm 0,62$ & $17,6 \pm 0,54^{*}$ \\
\hline & 2500 & $18,5 \pm 0,97$ & $16,8 \pm 0,65^{*}$ \\
\hline & Контроль & $19,4 \pm 0,80$ & $19,7 \pm 0,66$ \\
\hline
\end{tabular}

Примітка: * $-\mathrm{p}<0,05$.

При цьому відмічене суттєве $(\mathrm{p}<0,05)$ зниження кількості глікогену в тканині головного мозку під впливом ЕМП 2500 мкВт/см² через 2 місяці від початку впливу.

Як показали результати проведених досліджень, одночасно спостерігається під- вищення активності лактатдегідрогенази при

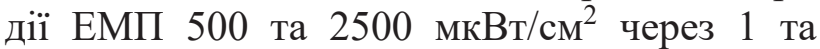
2 місяці досліду. Активація ферменту більш виражена у ранні строки дії факторів - на 30 добу (табл. 3).

Таблиця 3. Рівень лактатдегідрогенази та церулоплазміну в сироватці крові щурів при сумісній дії ЕМП, шуму 85 дБА та температури $15^{\circ} \mathrm{C}$.

\begin{tabular}{|c|c|c|c|}
\hline \multirow{2}{*}{ Показники } & \multirow{2}{*}{ ЕМП, мкВт/см² } & \multicolumn{2}{|c|}{ Період дії (місяці) } \\
\hline & & 1 місяць & 2 місяці \\
\hline \multirow{4}{*}{$\begin{array}{l}\text { Лактатдегідрогеназа в сироватці } \\
\text { крові, ммоль/л }\end{array}$} & 100 & $124,0 \pm 4,33$ & $129,0 \pm 7,03$ \\
\hline & 500 & $144,0 \pm 7,03 *$ & $140,0 \pm 7,57^{*}$ \\
\hline & 2500 & $148,0 \pm 6,49 *$ & $142,0 \pm 8,60 *$ \\
\hline & Контроль & $114,0 \pm 5,40$ & $116,0 \pm 5,90$ \\
\hline \multirow{4}{*}{$\begin{array}{l}\text { Церулоплазмін в сироватці крові, } \\
\text { ум.од. }\end{array}$} & 100 & $0,66 \pm 0,030$ & $0,67 \pm 0,026$ \\
\hline & 500 & $0,63 \pm 0,025$ & $0,66 \pm 0,030$ \\
\hline & 2500 & $0,58 \pm 0,026^{*}$ & $0,56 \pm 0,040^{*}$ \\
\hline & Контроль & $0,69 \pm 0,029$ & $0,68 \pm 0,030$ \\
\hline
\end{tabular}

Примітка: * $-\mathrm{p}<0,05$. 
Така направленість змін вмісту глікогену в органах супроводжувалась активацією лактатдегідрогенази в сироватці крові. У тварин, що зазнали дії ЕМП 500 та 2500

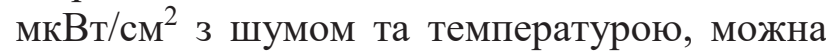
було спостерігати максимальне підвищення активності лактатдегідрогенази на $21 \%$ в порівнянні з контрольною групою.

Слід відзначити, що підвищення активності ферментів було стабільним протягом 2-х місяців впливу всіх досліджуваних рівнів фактору.

Зниження рівня глікогену та підвищення активності лактатдегідрогенази свідчить про посилення анаеробного гліколізу під впливом досліджуваного фактору. Інтенсифікація анаеробного гліколізу призводить до надлишкової продукції пірувата, подальша утилізація якого лімітується дефіцитом кисню у дихальному ланцюгу. Перетворення надлишку пірувата у лактат активізується підвищенням лактатдегідрогенази, яка $\epsilon$ ключовим ферментом в регуляції співвідношення процесів гліколізу та дихання.

В цей же термін відмічено зниження рівня церулоплазміну в сироватці крові щу-

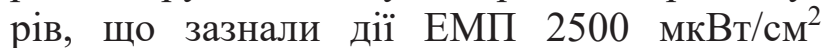

(табл. 3). Зниження антиоксидантної активності церулоплазміну склало 16\% по відношенню до контрольної групи тварин.

Проведені дослідження показали, що таке сполучення факторів чинить вплив на мембраностуктуровані ферменти циклу Кребса і супроводжується підключенням компенсаторного процесу енергоутворення. Тісно пов'язаний 3 окислювальними процесами, гліколітичний шлях перетворення енергії має компенсаторне значення. Про інтенсивність гліколізу свідчить стійке зниження рівня глікогену в тканинах печінки та головного мозку.

Отримані результати свідчать про можливі порушення метаболічних процесів, що проявляється зсувами в енергетичному обміні. Поєднана дія ЕМП, шуму та температури інтенсифікує анаеробний гліколіз, та призводить до функціонального превалювання над окисним гліколітичним процесом. Пригнічення кінцевих ферментів дихального ланцюга - цитохромоксидаз як ферментівмаркерів мембран, вказує на дестабілізацію мембран мітохондрій при порушенні ефективного процесу окисного енергоутворення.

\section{Висновок}

Таким чином, зіставлення отриманих результатів дозволило зазначити, що вираженість ефекту дії сполучення фактопів проявляється з терміном експозиції. Оскільки рівень шуму та температури були постійними в групах з різними рівнями ЕМП, то можна припустити визначальну залежність біоефектів від величини діючого рівня ЕМП при сумісній дії 3 шумом 85 дБА і температурою $15^{\circ} \mathrm{C}$.

\section{ЛІТЕРАТУРА}

1. Томашевська Л.А., Кравчун Т.Є., Обухан К.І., Лемешко Л.П. Цитологічні показники у щурів за дії неіонізуючого та іонізуючого навантаження // Гігієна населених місць : зб. наук. пр. - Київ, 2010. - Вип.55. - С. 209-212.

2. Томашевська Л.А., Кравчун Т.С., Лемешко Л.П., Бугаєнко О.О. Структурнофункціональні зміни в організмі щурів при дії електромагнітних випромінювань // Актуальні питання гігієни та екологічної безпеки України : зб. тез доповідей науково-практ. конф. - Київ, 2011. - С. 112-113.

3. Данилова Л. А. Справочник по лабораторным методам исследования / Л.А. Данилова. СПб.: Питер, 2003. - 736 с.

4. Камышников В.С. Справочник по клинико-биохимическим исследованиям и лабораторной диагностике / В.С. Камышников. - 3-е изд. - М. : МЕД пресс информ, 2009. - 896 с.

5. Антомонов М.Ю. Математическая обработка и анализ медико-биологических данных / М.Ю. Антомонов. - 2-е изд. - К.: МИЦ «Мединформ», 2017. - 579 с.

6. «OECD. Principles of Good Laboratory Practice». 1996. 


\title{
ВЛИЯНИЕ СОЧЕТАННОГО ДЕЙСТВИЯ ЭЛЕКТРОМАГНИТНОГО ПОЛЯ, ШУМА И ТЕМПЕРАТУРЫ НА ПОКАЗАТЕЛИ ЭНЕРГЕТИЧЕСКОГО ОБМЕНА В ОРГАНИЗМЕ ЖИВОТНЫХ
}

Томашевская Л.А., Кравчун Т.Е., Никитина Н.Г.

Целью работы было изучение влияния сочетанного действия электромагнитного излучения, шума и температуры в субхроническом эксперименте на биохимические показатели. Функциональные изменения оценивали по активности ферментов лактатдегидрогеназы и церулоплазмина в крови, а также по уровню цитохромоксидазы, сукцинатдегидрогеназы в митохондриях печени и головного мозга и содержанию гликогена в гомогенатах тканей.

Установлено, что сочетанное действие изучаемых факторов оказывает влияние на изменение соотношения аеробного и анаеробного прочессов энергетического обмена и сопровождается компенсаторной стимуляиией анаэробного энергообразования, что в свою очередь приводит к инициации окислительных процессов. Выраженность этих изменений зависела от воздействия исследуемого сочетания факторов, поскольку уровень шума и температуры были постоянными в группах с разными уровнями ЭМП, то можно предположить определяюшую зависимость биоэффектов от величины действующего уровня ЭМП при совместном действии с шумом 85 ДБА и температурой $15^{\circ} \mathrm{C}$.

\section{EFFECT OF COMBINED EFFECTS OF EMF, NOISE AND TEMPERATURE ON THE INDICATORS OF ENERGY EXCHANGE IN ANIMAL ORGANISM} L.A. Tomashevskaya, T.E. Kravchun, N.G. Nikitina

The aim of the work was to study the effect of the combined effect of electromagnetic radiation, noise and temperature in a subchronic experiment on biochemical parameters. Functional changes were assessed by the activity of the enzymes lactatedehydrogenase and ceruloplasmin in the blood, as well as by the level of cytochromeoxidase, succinatedehydrogenase in the liver and brain mitochondria and the glycogen content in the tissue homogenates.

It has been established that the combined effect of the studied factors influences the change in the ratio of aerobic and anaerobic energy metabolism and is accompanied by compensatory stimulation of anaerobic energy production, which in turn leads to the initiation of oxidative processes. The severity of these changes depended on the effect of the combination of factors under study, since the noise level and temperature were constant in groups with different levels of EMF, we can assume the decisive dependence of bioeffects on the magnitude of the current level of EMF under joint action with noise $85 \mathrm{~dB}$ and temperature $15^{\circ} \mathrm{C}$.

УДК 613.164:613.5

\section{РОЗРАХУНКОВИЙ МЕТОД ВИЗНАЧЕННЯ РІВНІВ ЕКСПОЗИЦІї ШУМУ ВІД ПРОЛЬОТІВ ЛІТАКІВ}

\author{
Семашко П.В. \\ ДУ «Інститут громадського здоров'я ім. О.М. Марзєєва НАМН України», м. Київ
}

Згідно з публікацією ВООЗ «Здоровая окружающая среда - здоровые люди» [1] в Європі шумове забруднення вважається одним 3 головних небезпечних чинників навколишнього середовища, які впливають на соматичне і психічне здоров'я і благополуч- чя. Надмірний шум завдає великої шкоди здоров'ю і заважає людям в їх повсякденних заняттях в школі, на роботі, вдома і в години дозвілля. Сьогодні наукові дослідження вказують на ще більш тісний зв'язок між впливом шуму - особливо створюваного дорож- 